\title{
HUBUNGAN BEBAN KELUARGA DENGAN NIAT PEMASUNGAN PASIEN SKIZOFRENIA WILAYAH KERJA UPTD PUSKESMAS II DENPASAR TIMUR
}

\section{THE RELATIONSHIP OF FAMILY BURDEN WITH THE STOCKS SCHIZOPHRENIC PATIENT OF UPTD PUSKESMAS II WORKING AREA EAST DENPASAR}

\author{
Ni Putu Riski Damayanti ${ }^{1}$, Ni Luh Putu Thrisna Dewi ${ }^{2}$, Desak Made Ari Dwi Jayanti ${ }^{3}$ \\ Sekolah Tinggi Ilmu Kesehatan Wira Medika Bali ${ }^{123}$
}

\begin{abstract}
ABSTRAK
Keluarga sebagai sistem pendukung utama sering mengalami beban yang tidak ringan dalam memberikan perawatan selama pasien di rumah, jika keluarga terbebani kemungkinan keluarga tidak mampu merawat pasien dengan baik sehingga keluarga mengambil keputusan untuk melakukan pemasungan. Pemasungan merupakan pelanggaran hak asasi manusia berat, karena dilakukan pada orang dengan disabilitas yang mengakibatkan tidak mampu mengakses layanan yang dapat mengurangi tingkat disabilitasnya. Tujuan dari penelitian ini adalah untuk menganalisis hubungan beban keluarga dengan pemasungan pada pasien skizofrenia di Wilayah Kerja UPTD Puskesmas II Denpasar Timur. Penelitian ini menggunakan desain deskriptif korelasional dengan pendekatan cross sectional, dengan teknik sampling purposive sampling. Sampel penelitian ini adalah 95 keluarga pasien dengan skizofrenia. Pengumpulan data menggunakan kuesioner beban keluarga dan KKPD. Hasil penelitian menunjukkan beban keluarga merawat pasien skizofrenia sebagian besar dalam kategori tinggi yaitu sebanyak 46 orang $(48,4 \%)$. Keinginan keluarga untuk melakukan pemasungan pada pasien skizofrenia sebagian besar dalam kategori tinggi yaitu sebanyak 42 orang (44,2\%). Hasil uji Rank Spearman didapatkan $p$-value $=0,000<0,05$ hasil ini menunjukkan ada hubungan bermakna beban keluarga dengan pemasungan pada pasien skizofrenia di Wilayah Kerja UPTD Puskesmas II Denpasar Timur. Di sarankan kepada Puskesmas II Denpasar Timur untuk meningkatkan frekuensi kegiatan penyuluhan untuk keluarga pasien yang memiliki keinginan tinggi untuk melakukan pemasungan guna mencegah tindakan pemasungan benar-benar dilakukan.
\end{abstract}

Kata Kunci: beban keluarga, pemasungan, skizofrenia

\section{ABSTRACT}

Family as the first supporting system is often run into the heavy encumbrance in giving treatment when the patient is at home if the family is burdened because of that, it might be the family can 't treat the patient well, so they make a decision to do stocks. It is a violation of human rights because it is undergone by the disabilities people that make them can't access the service which is able to alleviate their disability levels. The aim of the research is to analyze the relation of family encumbrance with the stocks to the patient of 
Bali Medika Jurnal.

Vol 7 No 1, 2020: 1-10

ISSN : 2615-7047

DOI: https://doi.org/10.36376/bmj.v7i1

schizophrenia at the working area of UPTD Puskesmas II, East Denpasar. This research applies correctional descriptive design with a cross-sectional approach, with purposive sampling technique. 95 people from the schizophrenic patient's family members are the sample of this research. Collecting the data utilizes the questionnaire of family encumbrance and KKPD. The result shows that the family burden because of treating schizophrenia patient is in the high category, it is 46 people (48.4\%). The family's desire to do stocks toward the schizophrenic patient is in the high category, it is 42 people $(44.2 \%)$. The result of Rank Spearman test is gained that p-value $=0.000<0.05$, this result shows that there is a meaningful relationship of the family burden with stocks on the schizophrenic patient at the working area of Puskesmas II, East Denpasar. It is recommended to Puskesmas II, East Denpasar to increase the frequency of counseling activity to the patient's family members, which have a high eagerness to do the stocks in order to prevent that behavior is really done.

Keywords: family encumbrance, stocks, schizophrenia

$$
\begin{array}{ll}
\hline \text { Alamat Korespondensi } & \text { : Br. Saih, Peguyangan Kaja, Denpasar Utara, Bali, } 80115 \\
\text { Email } & \text { : riski.damayanti63@yahoo.co.id }
\end{array}
$$

\section{PENDAHULUAN}

Pasien gangguan jiwa pada jaman era globalisasi mengalami peningkatan dari tahun ke tahun. Salah satu penyebab bertambahnya pasien gangguan jiwa adalah beban hidup yang semakin berat dialami seseorang (Zainuddin, 2016). Bentuk gangguan kejiwaan yang memiliki tingkat keparahan yang tinggi adalah skizofrenia. Skizofrenia merupakan gangguan jiwa berat yang akan membebani masyarakat sepanjang hidup penderita yang dikarakteristikan dengan disorganisasi pikiran, perasaan dan perilaku (Sinaga, 2015).

Data World Health Organization (WHO) tahun 2018 memperkirakan bahwa $1 \%$ populasi penduduk dunia menderita skizofrenia atau sekitar 21 juta orang (Kemenkes RI, 2018a). Hasil riset kesehatan dasar (Riskesdas) tahun 2018 menunjukkan data prevalensi gangguan jiwa berat, seperti skizofrenia di Indonesia mencapai sekitar 14 juta orang atau sebanyak 7 per 1.000 penduduk, jumlah pasien skizofrenia meningkat dibandingkan hasil Riskesdas 2013 sebanyak 400.000 orang atau sebanyak 1,7 per 1.000 penduduk. Hasil Riskesdas 2018 menunjukkan Provinsi Bali memiliki prevalensi skizofrenia tertinggi di Indonesia sebanyak 11 per 1.000 penduduk, jumlah pasien skizofrenia meningkat dibandingkan hasil Riskesdas 2013 sebanyak 2,3 per 1.000 penduduk (Kemenkes RI, 2018b). Data yang diperoleh dari Dinas Kesehatan Kota Denpasar pada tahun 2017 tercatat 496 pasien skizofrenia yang tersebar pada 11 Puskesmas yang ada di Kota Denpasar dan RSUD Wangaya Kota Denpasar. Pada tahun 2018 meningkat menjadi 536 pasien (Dinkes Denpasar, 2018).

Pemasungan merupakan permasalahan bidang kesehatan jiwa di Indonesia yang menunjukkan pasien gangguan jiwa belum sepenuhnya mendapatkan perlakuan yang baik serta memenuhi hak asasi manusia (Kemenkes RI, 2018a). Hasil Riset Kesehatan Dasar tahun 2018 memperkirakan jumlah pasien skizofrenia yang mengalami pemasungan di seluruh Indonesia mencapai 11,2\%. Angka 
pemasungan di pedesaan adalah sebesar 18,2\%. Angka ini lebih tinggi jika dibandingkan dengan angka di perkotaan, yaitu sebesar 10,7\% (Halida, 2015). Metode pemasungan tidak hanya dilakukan secara tradisional dengan menggunakan kayu atau rantai pada kaki, tetapi juga tindakan pengekangan yang membatasi gerak, pengisolasian, termasuk mengurung dan penelantaran, yang menyertai salah satu metode pemasungan (Kemenkes RI, 2018a). Di Indonesia, tahun 2009, jumlah kasus penderita gangguan jiwa dipasung yang ditemukan berjumlah 213 orang dan 170 orang diantaranya dibebaskan dan mendapat pelayanan medik. Sampai Desember 2014, 57.000 penderita gangguan jiwa di pasung, namun hanya 5.846 orang atau sekitar $10 \%$ yang dibebaskan dari pasung dan ditangani oleh tenaga kesehatan. Data terakhir 2018 jumlah kasus penderita gangguan jiwa yang dipasung ditemukan sebanyak 8543 dengan 7806 kasus dibebaskan dan mendapat pengobatan medik (Kemenkes RI, 2018a). Data jumlah pasien pasung di Provinsi Bali yang diketahui di pasung oleh keluarganya tahun 2017 mencapai 30 orang di seluruh Bali meningkat menjadi 55 orang pada tahun 2018 (Rumah Sakit Jiwa Provinsi Bali, 2018). Di Wilayah Kerja UPTD Puskesmas II Denpasar Timur jumlah pasien dengan riwayat pernah dipasung sebanyak 1 orang dan sudah dibebaskan. Metode pemasungan yang dilakukan oleh keluarga dengan mengurung pasien pada suatu ruangan yang terpisah dengan anggota keluarga yang lain. Alasan keluarga melakukan pemasungan adalah jika pasien dibiarkan bebas di khawatirkan membahayakan dirinya sendiri dan orang lain.

Hasil studi pendahuluan yang dilakukan di Puskesmas II Denpasar Timur, tercatat yaitu sebanyak 124 pasien skizofrenia. Informasi yang diperoleh dari UPTD Puskesmas II Denpasar Timur, 1 orang keluarga yang pernah melakukan pemasungan didapatkan data alasan dilakukan pemasungan karena pasien sering kumat jika dibiarkan bebas di khawatirkan membahayakan dirinya sendiri dan orang lain. Serta keluarga merasa tidak berdaya terhadap tekanan masyarakat sekitar yang merasa terancam dengan perilaku pasien.

Berdasarkan beberapa penelitian diatas, maka peneliti tertarik untuk melakukan penelitian tentang hubungan beban keluarga dengan pemasungan pada pasien skizofrenia di wilayah kerja UPTD Puskesmas II Denpasar Timur. Penelitian ini bertujuan untuk mengetahui beban keluarga, baik dari segi ekonomi, banyaknya kewajiban yang harus dilakukan untuk pasien, atau tekanan masyarakat, dan menganalisis hubungan beban keluarga dengan niat atau keinginan keluarga untuk melakukan pemasungan pada pasien skizofrenia di Wilayah Kerja UPTD Puskesmas II Denpasar Timur.

\section{METODE PENELITIAN}

Penelitian ini adalah penelitian bersifat kuantitatif dengan desain penelitian yang digunakan yaitu deskriptif korelasional yaitu bertujuan untuk menggambarkan hubungan antara dua variabel atau lebih, yaitu erat atau tidaknya hubungan, arah hubungan dan berarti atau tidaknya hubungan. Penelitian ini menggunakan pendekatan cross sectional dimana peneliti melakukan observasi satu kali saja dan pengukuran variabel bebas dan variabel terikat pada saat pemeriksaan atau pengkajian data.

Populasi dalam penelitian ini adalah semua keluarga pasien skizofrenia di Wilayah Kerja UPTD Puskesmas II Dennpasar Timur sebanyak 124 orang. 
Bali Medika Jurnal.

Vol 7 No 1, 2020: 1-10

ISSN : 2615-7047

DOI: https://doi.org/10.36376/bmj.v7i1

Penelitian ini telah dilakukan di Wilayah Kerja UPTD Puskesmas II Denpasar Timur pada tanggal 25 September - 3 November 2019. Variabel independen dalam penelitian ini adalah beban keluarga. Variabel dependen dalam penelitian ini adalah pemasungan pasien skizofrenia. Instrument atau alat pengumpulan data pada penelitian menggunakan kuesioner yang terdiri dari tiga bagian yaitu data karakteristik keluarga, petunjuk pengisian dan daftar pertanyaan mengenai beban keluarga dan pemasungan pasien skizofrenia dengan menggunakan skala ordinal. Tehnik analisis data yang digunakan pada penelitian ini yaitu analisis univariat dan analisis bivariat dengan tingkat signifikansi nilai $\mathrm{a} \leq 0,05$.

\section{HASIL}

\section{HASIL DAN PEMBAHASAN}

Tabel 4.1

Distribusi Frekuensi Responden Berdasarkan Data Karakteristik Keluarga di Wilayah kerja UPTD Puskesmas II Denpasar Timur Tahun 2019

\begin{tabular}{clcc}
\hline \multirow{2}{*}{ No } & \multirow{2}{*}{ Umur } & \multicolumn{2}{c}{ Hasil Penelitian } \\
\cline { 3 - 4 } & & 6 & Frekuensi (f) \\
\hline 1 & $18-25$ th (Dewasa Awal) & 9 & 6.3 \\
2 & $26-35 \quad$ th (Dewasa & $9 \%)$ & 9.5 \\
3 & Tengah) & 14 & 14.7 \\
$46-45$ th (Dewasa Muda) & 66 & 69.5 \\
\hline 4 & $46-55$ th (Dewasa Madya) & & \\
\hline & Pendidikan & 19 & 20.0 \\
\hline 1 & SD & 40 & 42.1 \\
2 & SMP & 36 & 37.9 \\
3 & SMA & & 9.5 \\
\hline & Pekerjaan & 9 & 48.4 \\
\hline 1 & Petani & 46 & 42.1 \\
\hline 3 & Swasta & 40 & 100.0 \\
\hline
\end{tabular}

Berdasarkan Tabel 4.1 berdasarkan umur menunjukkan bahwa sebagian besar responden berumur 46-55 tahun yaitu sebanyak 66 responden $(69,5 \%)$. Berdasarkan pendidikan menunjukkan bahwa sebagian besar responden berpendidikan SMP yaitu sebanyak 40 responden (42,1\%). Berdasarkan pekerjaan menunjukkan bahwa sebagian besar pekerjaan responden adalah pegawai swasta sebanyak 46 responden $(48,4 \%)$.

Tabel 4.2

Distribusi Frekuensi Beban Keluarga dan Pemasungan Pada Pasien Skizofrenia di Wilayah kerja UPTD Puskesmas II Denpasar Timur Tahun 2019

\begin{tabular}{clcc}
\hline No & Beban Keluarga & Frekuensi (f) & Persentase (\%) \\
\hline 1 & Rendah & 15 & 15.8
\end{tabular}


Bali Medika Jurnal.

Vol 7 No 1, 2020: 1-10

ISSN : 2615-7047

DOI: https://doi.org/10.36376/bmj.v7i1

\begin{tabular}{llcc}
2 & Sedang & 34 & 35.8 \\
3 & Tinggi & 46 & 48.4 \\
\hline & Pemasungan & & \\
\hline 1 & Rendah & 13 & 13.7 \\
2 & Sedang & 40 & 42.1 \\
3 & Tinggi & 42 & 44.2 \\
\hline & Total & 95 & 100.0 \\
\hline
\end{tabular}

Berdasarkan Tabel 4.2 menunjukkan bahwa beban keluarga merawat pasien skizofrenia sebagian besar dalam kategori tinggi yaitu sebanyak 46 orang (48,4\%). Dan pemasungan menunjukkan bahwa keinginan keluarga melakukan pemasungan pada pasien skizofrenia sebagian besar dalam kategori tinggi yaitu sebanyak 42 orang $(44,2 \%)$.

Tabel 4.3

Hasil Analisis Hubungan Beban Keluarga Dengan Pemasungan Pasien Skizofrenia di Wilayah Kerja UPTD Puskesmas II Denpasar Timur Tahun 2019

\begin{tabular}{|c|c|c|c|c|c|c|c|c|c|c|c|}
\hline \multirow{3}{*}{ No } & \multirow{3}{*}{$\begin{array}{c}\text { Beban } \\
\text { Keluarg } \\
\mathbf{a}\end{array}$} & \multicolumn{6}{|c|}{ Pemasungan } & & & \multirow[b]{2}{*}{$\begin{array}{c}\text { Koefisien } \\
\text { si } \\
\text { Kolerasi }\end{array}$} & \multirow[b]{2}{*}{ p value } \\
\hline & & \multicolumn{2}{|c|}{ Rendah } & \multicolumn{2}{|c|}{ Sedang } & \multicolumn{2}{|c|}{ Tinggi } & \multicolumn{2}{|c|}{ Total } & & \\
\hline & & f & $\%$ & f & $\%$ & f & $\%$ & $\mathbf{f}$ & $\%$ & \multirow{5}{*}{0,882} & \multirow{5}{*}{$\begin{array}{c}0,00 \\
0\end{array}$} \\
\hline 1 & Rendah & 13 & 86,7 & 2 & 13,3 & 0 & 0 & 15 & 100 & & \\
\hline 2 & Sedang & 0 & 0 & 32 & 94,1 & 2 & 5,9 & 34 & 100 & & \\
\hline 3 & Tinggi & 0 & 0 & 6 & 13 & 40 & 87 & 46 & 100 & & \\
\hline & Total & 13 & 13,7 & 40 & 42,1 & 42 & 44,2 & 95 & 100 & & \\
\hline
\end{tabular}

Berdasarkan uraian Tabel 4.3 menunjukkan bahwa keluarga yang memiliki beban rendah merawat pasien skizofrenia sebagian besar $(86,7 \%)$ memiliki keinginan rendah untuk pemasungan pada pasien skizofrenia, keluarga yang memiliki beban sedang merawat pasien skizofrenia sebagian besar $(94,1 \%)$ memiliki keinginan sedang untuk pemasungan pada pasien skizofrenia, keluarga yang memiliki beban tinggi merawat pasien skizofrenia sebagian besar $(87 \%)$ memiliki keinginan yang tinggi untuk pemasungan pada pasien skizofrenia. Berdasarkan hasil uji Rank Spearman didapatkan angka p value sebesar 0,000< dari tingkat signifikansi ditentukan yaitu 0,05 . Hasil ini menunjukkan ada hubungan bermakna beban keluarga dengan pemasungan pasien skizofrenia di wilayah kerja UPTD Puskesmas II Denpasar Timur. Hasil uji Spearman Rho juga didapat nilai koefisiensi kolerasi sebesar 0,882 dapat diartikan bahwa variabel beban keluarga dengan pemasungan pasien derajat hubungan yang kuat.

\section{PEMBAHASAN}

\section{Mengidentifikasi Beban Keluarga}

Hasil penelitian menunjukkan bahwa beban keluarga pada pasien skizofrenia sebagian besar dalam kategori tinggi yaitu sebanyak 46 orang $(48,4 \%)$. Berdasarkan hasil kuesioner didapat bahwa responden yang mengalami beban 
tinggi ternyata lebih banyak yang mengalami beban subjektif yaitu selalu kesal pekerjaan terganggu karena harus mengurus anggota keluarga yang menderita gangguan jiwa dan tinggal satu rumah dengan anggota keluarga yang menderita gangguan jiwa menambah pekerjaan menjadi berat. Keluarga sebagian besar memiliki beban yang tinggi merawat pasien skizofrenia menurut Nuraenah (2015) keluarga dengan gangguan jiwa, stressor yang dihadapi berbeda dengan keluarga dengan dengan masalah kesehatan lain. Selain berkaitan dengan biaya yang dikeluarkan untuk perawatan, ketidakmampuan klien dalam memenuhi kebutuhan sehari-hari juga pada stigma masyarakat pada klien gangguan jiwa. Stressor yang dialami oleh keluarga dengan gangguan jiwa sering dikenal dengan beban keluarga (family burden).

Menurut Daulima (2014) keluarga sebagai sistem pendukung utama sering mengalami beban yang tidak ringan dalam memberikan perawatan selama pasien dirawat di rumah sakit maupun setelah kembali ke rumah. Beban tersebut yaitu beban finansial dalam biaya perawatan, beban mental dalam menghadapi perilaku pasien, dan beban sosial terutama menghadapi stigma dari masyarakat tentang anggota keluarganya yang mengalami gangguan jiwa.

Hasil penelitian yang didapat sesuai dengan penelitian sebelumnya yang dilakukan oleh Suryaningrum (2013) menunjukkan beban keluarga merawat pasien skizofrenia di Poliklinik RS Marzoeki Mahdi Bogor sebagian besar pada kategori beban berat. Penelitian Suryenti (2017) menunjukkan beban keluarga merawat pasien skizofrenia di Klinik Jiwa Rumah Sakit Jiwa Provinsi Jambi sebagian besar pada kategori beban berat.

Menurut pendapat peneliti keluarga memiliki beban tinggi merawat pasien gangguan jiwa, hal ini bisa disebabkan oleh faktor sosial ekonomi dan pendidikan yang rendah. Hal ini sesuai dengan karakteristik keluarga yang sebagian besar adalah pegawai swasta dengan pendapatan atau gaji standar UMR dan sebagian besar berpendidikan SMP. Status tingkat pendidikan rendah kurang memiliki informasi yang cukup terkait dengan pengetahuan penyakit dan perawatannya dalam memberikan perawatan, bahwa tingkat pendidikan seseorang dapat mempengaruhi kemampuan untuk menyerap informasi, menyelesaikan masalah, dan berperilaku baik. Pendidikan rendah berisiko ketidakmampuan dalam merawat kesehatannya. Kondisi ini dapat menyebabkan meningkatnya stres emosional dan ekonomi dari keluarga adalah tingkat pengalaman distress keluarga sebagai efek dari kondisi anggota keluarganya. Selain itu keluarga yang merawat anggota keluarga dengan skizofrenia mengalami reaksi emosi terhadap gangguan dan stigma sosial yang ditimbulkan karena perilaku pasien.

Hasil penelitian ini juga menunjukkan sebanyak 15 orang $(15,8 \%)$ memiliki beban rendah hal ini dapat dipengaruhi oleh kemampuan keluarga mendapatkan informasi-informasi penting dalam upaya meningkatkan status kesehatan anggota keluarganya yang mengalami gangguan jiwa terutama informasi tentang cara merawat pasien skizofrenia dari petugas kesehatan sehingga keluarga dalam memberikan perawatan kepada pasien tidak terlalu terbebani, disamping itu adanya dukungan orang-orang sekitar menjadikan lebih kuat, sehingga mampu dalam menjalani perannya merawat pasien sehingga dapat mempengaruhi beban keluarga menjadi lebih rendah. Beban rendah yang dialami keluarga dalam merawat pasien skizofrenia disamping dipengaruhi oleh informasi dan dukungan dapat juga dipengaruhi oleh tingkat ketergantungan pasien dalam perawatan diri, semakin 
mandiri tingkat ketergantungan pasien maka beban keluarga akan semakin rendah karena keluarga tidak perlu membantu pasien secara total dalam perawatan diri tetapi hanya mengarahkan dan membimbing pasien.

\section{Mengidentifikasi Pemasungan Pada Pasien Skizofrenia}

Hasil penelitian menunjukkan bahwa keinginan keluarga melakukan pemasungan pada pasien skizofrenia sebagian besar dalam kategori tinggi yaitu sebanyak 42 orang (44,2\%). Menurut Syarniah (2014) penyebab penderita gangguan jiwa berat seperti skizofrenia dilakukan pemasungan adalah karena dampak sosial berupa penolakan, pengucilan dan diskriminasi. Dampak ekonomi dapat berupa hilangnya hari produktif untuk mencari nafkah bagi pasien maupun keluarga yang harus merawat, tingginya biaya perawatan yang harus ditanggung keluarga maupun masyarakat dan stigma yang menyertai pasien skizofrenia.

Menurut Minas dan Diatri (2015) faktor keluarga melakukan pemasungan diantaranya untuk Mencegah pasien melakukan tindak kekerasan yang dianggap membahayakan terhadap dirinya atau orang lain. Selain itu upaya untuk Mencegah pasien agar tidak kambuh (meninggalkan rumah, Perilaku kekerasan, isolasi sosial). Selain itu terdapat faktor kemiskinan dan rendahnya pendidikan keluarga merupakan salah satu penyebab pasien gangguan jiwa berat hidup terpasung. Ketidaktahuan pihak keluarga, rasa malu pihak keluarga, penyakit yang tidak kunjung sembuh, tidak adanya biaya pengobatan, dan tindakan keluarga untuk mengamankan lingkungan merupakan penyebab keluarga melakukan pemasungan. Salah satu kendala ekonomi kelurga berpengaruh pada biaya berobat yang harus ditanggung pasien tidak hanya meliputi biaya yang langsung berkaitan dengan pelayanan medik seperti harga obat, jasa konsultasi tetapi juga biaya spesifik lainnya seperti biaya transportasi ke rumah sakit dan biaya akomodasi lainnya.

Hasil penelitian ini didukung oleh hasil penelitian Lestari (2014) tentang kecenderungan atau sikap keluarga penderita gangguan jiwa terhadap tindakan pasung studi kasus di RSJ Amino Gondho Hutomo Semarang. Hasil penelitian menunjukkan sebanyak $39(48,8 \%)$ mempunyai sikap kurang mendukung terhadap tindakan pasung yaitu sejumlah 40 (50\%) (Lestari dan Wardhani, 2014). Penelitian Rohmadoni dan Mundzakir (2014) analisis faktor yang mempengaruhi keluarga melakukan pemasungan pada anggota keluarga dengan gangguan jiwa di Rumah Sakit Jiwa Menur Surabaya. Hasil penelitian menunjukkan sebagian besar yaitu 14 keluarga $(70 \%)$ keinginan keluarga untuk melakukan pemasungan pada pasien skizoprenia sebagian besar dalam kategori tinggi.

Peneliti berpendapat, keinginan keluarga untuk melakukan pemasungan pada pasien skizoprenia sebagian besar dalam kategori tinggi dapat disebabkan karena keterbatasan pengetahuan tentang kesehatan jiwa ditambah minimnya fasilitas pelayanan kesehatan jiwa di masyarakat mendorong keluarga untuk mengambil keputusan tindakan pasung. Disamping itu keinginan untuk melakukan pemasungan merupakan tindakan keluarga untuk melindungi anggota keluarganya yang gangguan jiwa dari tindakan anarkis masyarakat sekitamya. Pasien gangguan jiwa kronis yang cenderung agresif seringkali melakukan tindakan yang membahayakan orang lain dan lingkungan, seperti memukul, merusak fasilitas umum, dan mengamuk. Tindakan ini dapat memicu tindakan pembalasan dari orang lain atau masyarakat sekitar yang terkena dampak dari perilaku agresif pasien. 


\section{Hubungan Beban Keluarga Dengan Pemasungan Pada Pasien Skizofrenia}

Berdasarkan hasil uji Rank Spearman didapatkan angka p value sebesar $0,000<$ dari tingkat signifikansi ditentukan yaitu 0,05 . Hasil ini menunjukkan ada hubungan bermakna beban keluarga dengan pemasungan pasien skizofrenia di wilayah kerja UPTD Puskesmas II Denpasar Timur. Hasil uji Spearman Rho juga didapat nilai koefisiensi kolerasi sebesar 0,882 dapat diartikan bahwa variabel beban keluarga dengan pemasungan pasien derajat hubungan yang kuat. Hasil penelitian ini didukung oleh Daulima (2014) yang mengatakan keluarga yang memiliki anggota keluarga menderita skizofrenia sering mengalami beban yang tidak ringan dalam memberikan perawatan selama pasien dirawat di rumah sakit maupun setelah kembali ke rumah. Dampak dari beban yang dirasakan keluarga akan mempengaruhi kemampuan keluarga dalam merawat pasien. Jika keluarga terbebani kemungkinan keluarga tidak mampu merawat pasien dengan baik sehingga keluarga mengambil keputusan untuk melakukan pemasungan.

Menurut Syarniah (2014) banyak alasan yang dijadikan keluarga sehingga mengambil keputusan untuk memasung. Selain alasan keamanan dan stigma masyarakat, kondisi sosial ekonomi dan kegagalan tindakan alternatif pra pasung juga membuat keluarga memutuskan untuk memasung keluarganya dengan ganguan jiwa. Idaiani dan Raflizar (2015) juga menjelaskan bahwa keluarga yang merawat anggota keluarga dengan sizofrenia dimana gejala yang paling sering muncul adalah perilaku kekerasan sehingga kelaurga akan mengalami reaksi emosi terhadap gangguan dan stigma sosial yang ditimbulkan karena perilaku kekerasan dengan dampak lainnya. Hal ini dapat diartikan bahwa Perilaku kekerasan yang dilakukan pasien terhadap keluarga sangat merugikan keluarga dan mempengaruhi sikap keluarga dalam merawat pasien perilaku kekerasan menjadi tidak baik sehingga membuat keluarga memutuskan untuk melakukan pemasungan.

Hasil penelitian yang didapat sesuai dengan hasil penelitian Jayanti dan Dharmawan (2018) tentang hubungan stigma keluarga dengan pemasungan pasien skizofrenia di Rumah Sakit Jiwa Provinsi Bali. Hasil penelitain menunjukkan menunjukkan terdapat hubungan antara stigma keluarga dengan pemasungan pasien skizofrenia dengan $p$ value $0,000<0,005$. Penelitian Ripangga (2018) tentang hubungan beban keluarga dengan sikap keluarga dalam merawat pasien skizofrenia di Poliklinik Rumah Sakit Jiwa Daerah Atma Husada Mahakam Samarinda. Hasil analisis menunjukan terdapat hubungan beban keluarga dengan sikap keluarga dalam merawat pasien skizofrenia dengan $p$ value $=0,000$.

Menurut pendapat peneliti, merawat anggota keluarga menderita skizofrenia membuat keluarga merasa terbebani karena gangguan jiwa skizofrenia termasuk gangguan jiwa berat yang memerlukan penanganan jangka panjang sehingga hal tersebut menjadi stressor bagi keluarga karena keluarga setiap hari akan menghadapi perilaku pasien seperti tiba-tiba gelisah dan mengamuk, setiap hari harus diawasi agar tidak menganggu lingkungan sehingga hal tersebut keluarga memiliki keinginan untuk melakukan tindakan pemasungan karena keluarga tidak berdaya terhadap tekanan masyarakat sekitar yang merasa terancam dengan perilaku pasien. Pada dasarnya keluarga tidak ingin memasung pasien karena merasa sayang kepada anggota keluarganya tersebut, namun tekanan secara psikis dari lingkungan sekitar yang sudah antipati dengan perilaku pasien memaksa keluarga untuk melakukan tindakan pasung. Kondisi ini menimbulkan konflik berat pada keluarga sebelum tindakan pasung dilakukan. Konflik ini terjadi karena 
pilihan tindakan memasung atau tidak memiliki konsekuensi yang sama beratnya. Dalam hal ini keputusan yang diambil keluarga sebenarnya tidak mudah dan kerapkali membutuhkan proses yang cukup panjang dengan mempertimbangkan segala konsekuensinya.

\section{Simpulan}

\section{SIMPULAN DAN SARAN}

Berdasarkan hasil penelitian di atas dapat dirumuskan simpulan sebagai berikut: Beban keluarga merawat pasien skizofrenia sebagian besar dalam kategori tinggi. Semakin berat gangguan jiwa pasien, semakin besar keinginan keluarga untuk melakukan pemasungan. Pada dasarnya keluarga tidak ingin memasung pasien karena merasa sayang kepada anggota keluarganya tersebut, namun tekanan secara psikis dari lingkungan sekitar yang sudah antipati dengan perilaku pasien memaksa keluarga untuk melakukan tindakan pasung.

\section{Saran}

Berdasarkan hasil penelitian yang telah didapatkan, ada beberapa saran yang ingin penulis dikemukakan untuk dapat dipertimbangkan pelaksanaannya adalah sebagai berikut: Kepada UPTD Puskesmas II Denpasar Timur meningkatkan frekuensi kegiatan penyuluhan dan home visit untuk keluarga pasien yang memiliki keinginan tinggi untuk melakukan pemasungan untuk mencegah tindakan pemasungan benar-benar dilakukan. Bagi keluarga diharapkan untuk aktif mengikuti kegiatan-kegiatan yang berhubungan dengan peningkatan pemahaman tentang perawatan pasien dirumah seperti mengikuti penyuluhan-penyuluhan yang dilaksanakan oleh Puskesmas atau Rumah Sakit Jiwa. Bagi penelitian selanjutnya diharapkan dapat meneliti faktor-faktor lain yang mempengeruhi keinginan keluarga melakukan pemasungan seperti sosial ekonomi, stigma dan dukungan masyarakat. Dan diharapkan dalam pembuatan kuesioner menggunakan lebih dari satu sumber.

\section{DAFTAR PUSTAKA}

Daulima, N. H. C. (2014). Proses Pengambilan Keputusan Tindakan Pasung oleh Keluarga terhadap Klien Gangguan Jiwa. Universitas Indonesia.

Dinkes Denpasar. (2018). Profil Kesehatan Kota Denpasar 2018.

Halida, N. (2015). Pengalaman Keluarga dalam Pemenuhan Kebutuhan Perawatan Diri pada Orang Dengan Gangguan Jiwa (ODGJ) dengan Pasung di Kecamatan Ambulu Kabupaten Jember. Universitas Jember.

Idaiani, \& Raflizar. (2015). Faktor yang Paling Dominan terhadap Pemasungan Orang dengan Gangguan Jiwa di Indonesia. Badan Litbang Kesehatan Kemenkes RI.

Jayanti, \& Dharmawan. (2018). Hubungan Stigma Keluarga D dengan Pemasungan Pasien Skizofrenia di Rumah Sakit Jiwa Provinsi Bali. Jurnal Ners Dan Kebidanan Indonesia, 6(2), 97-104.

Kemenkes RI. (2018a). Menuju Indonesia Bebas Pasung. Jakarta: Pusat Komunikasi Publik, Sekretariat Jendral Kementerian Kesehatan RI. 
http://www.depkes.go.id/index.php/berita/press-release/1242-menujuindonesia

Kemenkes RI. (2018b). Riset Kesehatan Dasar. Badan Penelitian dan Pengembangan Kesehatan Kementerian Kesehatan RI.

Lestari. (2014). Kecenderungan atau Sikap Keluarga Penderita Gangguan Jiwa terhadap Tindakan Pasung (Studi Kasus di RSJ Gondho Hutomo Semarang). Jurnal Keperawatan Jiwa, 2(1), 14-23.

Lestari, W., \& Wardhani, Y. F. (2014). Stigma dan Penanganan Penderita Ganguan Jiwa Berat yang Dipasung. Buletin Penelitian Sistem Kesehatan, 17(2), $157-166$.

Minas, \& Diatri. (2015). Pasung: Physical Restraint and Confinement of The Mentally III in the Community. http://creativecommons.org

Nuraenah. (2015). Hubungan Dukungan Keluarga dan Beban Keluarga dalam Merawat Anggota dengan Riwayat Perilaku Kekerasan di RS Jiwa Islam Klender Jakarta Timur. Universitas Indonesia.

Ripangga. (2018). Hubungan Beban Keluarga dengan Sikap Keluarga dalam Merawat Pasien Skizofrenia di Poliklinik Rumah Sakit Jiwa Daerah Atma Husada Mahakam Samarinda. Universitas Muhammadiyah.

Rohmadoni, \& Mundzakir. (2014). Analisis Faktor yang Mempengaruhi Keluarga Melakukan Pemasungan pada Anggota Keluarga dengan Gangguan Jiwa di Rumah Sakit Jiwa Menur Surabaya. The SUN, 2(3).

Rumah Sakit Jiwa Provinsi Bali. (2018). Data Pasien Rawat Jalan dan Rawat Inap. Sinaga. (2015). Budaya Pasung dan Dampak Yurudis Sosiologis (Studi Tentang Upaya Pelepasan Pasung dan Pencegahan Tindakan Pemasungan di Kabbupaten Wonogiri). IJMS: Indonesia Journal on Medical Science, 1(2).

Suryaningrum. (2013). Hubungan antara Beban Keluarga dengan Kemampuan Keluarga Merawat Pasien Perilaku Kekerasan di Poliklinik Rumah Sakit Marzoeki Mahdi Bogor. Jurnal Keperawatan Jiwa, 1(2), 148-155.

Suryenti. (2017). Dukungan dan Beban Keluarga dengan Kemampuan Kekerasan di Klinik Jiwa Rumah Sakit Jiwa Provinsi Jambi Tahun 2017 Family Support and Burden Relationship with Family Ability Caring for Patients at Risk of Violence Behavior at Mental Clinic of Mental Hospita. Jurnal Psikologi, 2(2), 39-46.

Syarniah. (2014). Studi Deskritif Persepsi Masyarakat tentang Pasung pada Klien Gangguan Jiwa Berdasarkan Karakteristik Demografi di Desa Sungai Arpat Kecamatan Karang Intan Kabupaten Banjar. Jurnal Skala Kesehatan, 5(2).

WHO. (2018). Schizophrenia: Media Centre. World Health Organization. http://www.who.int/mediacentre/factsheets/fs397/en/

Zainuddin. (2016). Pendekatan Holistik pada Gangguan Jiwa Skizofrenia. Balai Penerbit FKUI. 